\title{
Orman Ürünleri Endüstrisinde Toplam Verimli Bakım Faaliyetlerinin İncelenmesi; İnegöl Örneği
}

\author{
${ }^{1}$ Birsu BOZKURT KÜÇÜK, ${ }^{2}$ Derya SEVIM KORKUT ${ }^{*}$ \\ ${ }^{1}$ Yüksek Orman Endüstri Mühendisi, İnegöl/Bursa \\ ${ }^{2}$ Düzce Üniversitesi Orman Fakültesi, Orman Endüstri Mühendisliği Bölümü, Düzce \\ "Sorumlu Yazar: deryasevimkorkut@duzce.edu.tr
}

Geliș Tarihi: 07.04.2016

\begin{abstract}
Özet
$\mathrm{Bu}$ çalışmada orman ürünleri endüstrisinde TVB faaliyetleri ile ilgili genel bir durumun belirlenmesi amaçlanmıştır. Bu amaçla Bursa/İnegöl'de faaliyet gösteren 77 orman ürünleri sanayi işletmesine yüzyüze görüşme yöntemi ile bir anket çalışması yapılmıştır. Anketlerden elde edilen veriler SPSS ortamında istatistiksel yöntemlerle değerlendirilmiştir. Çalışma sonucunda; işletmelerin \% 75.3 'ünde bakım bölümünün organizasyon şemasında bağımsız bir bölüm olarak yer aldığı, işletmelerin \%53.2'sinde bakım bölümünün gelişme gösterdiği belirlenmiştir. İşletmelerin sadece \%9.1'i TVB sistemini uyguladığını, \%19.5'i gelecek yıllarda TVB uygulamasına geçmeyi düşündüklerini \%22.1'i TVB uygulamasının ne olduğuna dair fikirlerinin olmadığını belirtmişlerdir. Ayrıca katılımcı işletmelerin değerlendirmelerine göre, TVB uygulayan işletmelerde verimlilik artışı, hurda oranında azalma, ekipman verimliliğinde artış, arızalarda azalma olduğu görülmüştür.

Anahtar Kelimeler: Bakım, İnegöl, Orman ürünleri endüstrisi, Toplam verimli bakım, TVB

\section{Investigation of Total Productive Maintenance Facilities in Forest Products Industry, Example of Inegöl}

Abstract

The aim of the study is to present the general condition of TPM facilities in forest products industry. For this purpose, face-to-face interviews with 77 forestry products industrialists in Bursa/Inegöl were conducted. Findings were analyzed on SPSS through statistics means. The study demonstrated that $75.3 \%$ of the companies have a maintenance department independent of the organizational chart and that $53.2 \%$ of the maintenance departments have shown development. Furthermore, only $9.1 \%$ of the enterprises use the TPM system, $19.5 \%$ consider switching to it in the future, while $22.1 \%$ are uninformed about the TPM. The study also finds that the TPM implementing companies have experienced efficiency increase in general and equipment efficiency in particular, and a decrease in both scrap and breakdown rates.
\end{abstract}

Key Words: Maintenance, Inegöl, Forest products industry, Total productive maintenance, TPM

\section{Giris}

Toplam verimli bakım (TVB), çalı̧anların bilgi ve becerilerinin artırılması, kullanılan ekipmanların en iyi şekilde korunması, tüm bakım faaliyetlerinin bilgisayar ortaminda takip edilmesi ve gerekli önlemlerin alınmasıyla sıfır kaza, sıfır hata ve sıfır plansız duruşu amaçlayan bir yönetim sistemidir (Akteke, 2007). TVB en yalın ifadeyle, bir fabrikada kullanılan ekipmanın verimliliğini ya da etkinliğini arttırmak ve olası makine hatalarından kaynaklanacak iskartaları önlemek amaciyla gerçekleștirilen tüm çalışmaları kapsayan bir felsefedir (Elvan, 2012).

TVB'nin tanımı aşağıdaki beş noktayı içerir (Nakajima, 1988; Öztürk, 1999; Bayram, 1998; Bozoğlu, 1998; Sevim Korkut, 2005; Akteke, 2007).
1. Ekipmanın en verimli şekilde kullanılmasını yani toplam verimi hedefler.

2. İşletme genelinde bakım koruması, koruyucu bakım ve iyileştirme amaçlı bakımı da içine alan TVB sistemi oluşturur.

3. Ekipman tasarımcılarının, operatörlerin ve bakım bölümünün katılımına gereksinim gösterir.

4. En üst yönetim kademesinden en alt kademeye kadar tüm elemanları kapsamı içine alır.

5. Kullanıcıların küçük grup faaliyetlerine dayalı verimli bakımı özendirir ve geliştirir.

TVB'deki “toplam" kavramı TVB'nin prensip özelliklerini içeren 3 anlama sahiptir. (Nakajima, 1988; Öztürk, 1999; Çelebi, 
1997; Ayy1ldız, 2000; Sevim Korkut, 2005; Akteke, 2007). Bunlar;

1. Toplam ekipman verimliliği: Ekonomik kârlılık ve verimliliği içerir.

2. Toplam bakım sistemi: Bakım koruma, onarılabilirliğin ve koruyucu bakımın geliştirilmesini sağlar.

3. Tüm çalışanların toplam katılımı: Küçük grup faaliyetleri ile operatörlerce yapılacak olan kullanıcı bakımı ifade eder.

Tanımdaki "toplam" ifadesinden de anlaşılacağı üzere TVB'nin başarısı için sadece bakım elemanlarının değil yönetim kademesi başta olmak üzere tüm çalışanların katılımı ve desteği gerekmektedir (Öztürk, 1999; Sevim Korkut, 2005; Akteke, 2007).

TVB'nin hedefleri; ana hedefi ve iş hedefi olmak üzere 2 grup altında incelenmektedir (Göktaş, 1997; Adal1, 1998; Öztürk, 1999; Sevim Korkut, 2005; Akteke, 2007; Demir, 2009).

Ana Hedefi: Altı büyük ekipman kaybının (ekipman arızası kayıpları, ekipmanı hazırlama ve ayarlama kayıpları, küçük duruş ve boşta çalışma kayıpları, hız kayıpları, kalite hataları ve yeniden ișleme kayıpları, ürün kayıpları ve başlangıç kayıpları) sıfıra veya en alt düzeye indirilerek ürün kalitesinin ve ekipman verimliliğinin arttırılmasının sağlanmasıdır.

İ̧̧ Hedefi: Dünya çapında başarı, müşteri memnuniyeti, rekabet edebilme gücü ve pazar payının arttırılması şeklinde siralanabilir.

Yukarıdaki hedeflere yönelmek için TVB'nin tek başına bir yönerge olmadığ belirtilmelidir. $\mathrm{Bu}$ hedeflere yönelmek için TVB'nin işletmenin çalışma biçimi, misyonu ve vizyonu gibi kavramlarla ilgili mantıksal bağ kurulmalı ve bu kavramlarla ortak hareket eden bir TVB sistemi oluşturulmalıdır (Geniş, 2007; Genç, 2007).

İşletmelerde başarılı TVB çalışmaları için; çalışma isteği ve motivasyon, yetenekli elemanlar ve işletmedeki tüm bölümlerin desteği olmak üzere üç faktör önem kazanmaktadır (Akteke, 2007). TVB ile üretim artışı ile birlikte işçilerin moral ve iş memnuniyeti de artmaktadır. Böylece hataları ve fiyatları azaltmak amaciyla ortak çalışan bakım ve üretim bölümleri arasındaki haberleşmenin gelişmesi sağlanmaktadır.
Geleneğin aksine üretim bölümü çalışanlarına bakım eğitiminin verilmesi, bakım meslektaşları tarafindan yerine getirilmektedir (Al-Hassan ve ark. 2000; Sevim Korkut, 2005).

\section{Materyal ve Yöntem}

İnegöl orman ürünleri endüstrisinde TVB ile ilgili genel bir durumun belirlenmesi amacıyla İnegöl Ticaret ve Sanayi Odası'na kayitlı (Anonim, 2012) 380 adet işletme çalışmanın evrenini oluşturmuştur. Bunu temsil edecek örneklem büyüklüğü $\% 95$ güven düzeyi ve $\% 10$ hata payı ile 77 olarak belirlenmiştir.

Anket formu her işletmeye Mart 2013 Temmuz 2014 dönemleri arasında yüz yüze görüşme yoluyla uygulanmıştır. Anket formu literatürdeki çalışmalardan (Sevim Korkut, 2005; Cihan, 2005; Aytin, 2006; Kekezoğlu, 2006; İşaşır, 2006; Akteke, 2007; Görener ve Yenen, 2007; Erdem, 2009; Tazegün, 2009; Doğan, 2010; Elvan, 2012) yararlanılarak hazırlanmıştır. Anket formunda işletmelerin bakım faaliyetleri ve uyguladıkları TVB uygulamaları ile ilgili sorulara yer verilmiştir. 77 işletmeden elde edilen anket verileri SPSS (2003) ortamına aktarılarak, istatistiksel yöntemlerle değerlendirilmiştir.

\section{Araştırmanın Kısıtları}

Çalışmada ele alınan veriler Bursa ili İnegöl ilçesinde faaliyette bulunan orman ürünleri sanayi işletmeleri özelinde sınırlı tutulmuştur. Bulgular ancak benzer koşullarda üretim yapan ya da benzer bakım yöntemlerini uygulayan işletmelere genellenebilecektir. Çalışmada veri elde etme aracı olarak kullanılan anket yönteminde mümkün olan en sağlıklı verinin elde edilmesi amaçlanmıştır. Anketler çoğu zaman çalışanların mesai saatlerinde uygulanmaya çalışılmıştır. $\mathrm{Bu}$ durum işletmelerin ya anketi cevaplamak istememelerine ya da tekrar tekrar aynı işletmeye gidilmesine neden olmuştur. İşletmelere tekrar tekrar gidilmesine rağmen anketlerin sayisal olarak yetersiz ama istatistiksel değerlendirmeler için yeterli olması çalışmanın anket yapılması aşamasındaki temel sinırlılıklarını değiştirmiştir. 


\section{Araştırmanın Güvenilirliği}

Araştırmada kullanılan ölçeğin güvenilirlik analizi sonucunda verilerin genel güvenilirlik değeri (Cronbach Alpha Katsayıs1) 0.77 olarak belirlenmiştir. Elde edilen bu sonuç dikkate alındığında, ölçeğin güvenilir olduğu görülmektedir (Özdamar, 2002).

\section{Bulgular ve Tartışma}

\section{Bakım Bölümünün Durumu}

İşletmelerin \%75.3'ünde bakım bölümü bağımsız bir bölüm olarak organizasyon șeması içerisinde yer almaktadır.

İşletmelerde makine gereksinimi olduğunda bakım bölümünün görüşüne işletmelerin \%53.2'sinde başvurulurken, \%23.4'ünde kismen başvurulmakta, $\% 23.4$ 'ünde ise başvurulmamaktadır. Bakım bölümünün görüşüne başvurmayan işletmeler (\%23.4) bunun nedenleri olarak bakım bölümünün henüz yeterli düzeyde olmadığını (\%55.6) ve dışarıdan, kaynağından çözüm aramanın daha kolay olduğunu (\%44.4) belirtmişlerdir (Tablo1).

Tablo 1. İșletmelerin bakım bölümünün durumu.

\begin{tabular}{|c|c|c|c|}
\hline & Seçenekler & $\begin{array}{l}\text { İşletme } \\
\text { Sıklığı }\end{array}$ & $\begin{array}{c}\text { Yüzde } \\
(\%)\end{array}$ \\
\hline \multirow{3}{*}{$\begin{array}{l}\text { İşletmenizde bakım bölümü bağımsız } \\
\text { bir bölüm olarak organizasyon } \\
\text { şeması içinde yer alıyor mu? }\end{array}$} & Evet & 58 & 75.3 \\
\hline & Hayır & 19 & 24.7 \\
\hline & Toplam & 77 & 100 \\
\hline \multirow{4}{*}{$\begin{array}{l}\text { İşletmenizde makine gereksinimi } \\
\text { olduğunda bakım bölümünün } \\
\text { görüşüne başvuruluyor mu? }\end{array}$} & Evet & 41 & 53.2 \\
\hline & Hayır & 18 & 23.4 \\
\hline & Kismen & 18 & 23.4 \\
\hline & Toplam & 77 & 100 \\
\hline \multirow{3}{*}{$\begin{array}{l}\text { Cevabınız Hayır ise bakım } \\
\text { bölümünün görüşüne başvurmama } \\
\text { nedenleriniz nelerdir? }\end{array}$} & $\begin{array}{l}\text { Bakım bölümü henüz yeterli düzeyde } \\
\text { değil }\end{array}$ & 10 & 55.6 \\
\hline & $\begin{array}{l}\text { Dişarıdan doğrudan kaynağından çözüm } \\
\text { aramak daha kolay }\end{array}$ & 8 & 44.4 \\
\hline & Toplam & 18 & 100 \\
\hline \multirow{3}{*}{ Bakım bölümünüz gelişiyor mu? } & Evet & 41 & 53.2 \\
\hline & Hayır & 36 & 46.8 \\
\hline & Toplam & 77 & 100 \\
\hline \multirow{3}{*}{$\begin{array}{l}\text { Verimliliği arttıran bakım } \\
\text { çalışmalarınızın başarısı için yeni } \\
\text { yatırımlar gerekli mi? }\end{array}$} & Evet & 28 & 36.4 \\
\hline & Hayır & 49 & 63.6 \\
\hline & Toplam & 77 & 100 \\
\hline
\end{tabular}

İșletmelerin $\quad \% 53.2$ 'sinde bakım bölümünün geliştiği $\% 46.8$ 'inde ise gelişmediği belirlenmiştir. İşletmeler bakım bölümlerinin gelişmesi için aldıkları önlemler olarak; bakım bölümünün organizasyon şemasında bağımsız bir bölüm olarak yer aldığını, $5 \mathrm{~S}$ çalışmalarının uygulandığını, malzeme listelerinin hazırlanarak yedek parça stoğuna geçildiğini, koruyucu ve kestirimci bakım yöntemlerini uyguladıklarını, bakım bölümünde $\mathrm{CNC}$ (Bilgisayarl1 Sayisal Kontrol-Computer Numerical Control) tezgahlar için fason destek alındığını, makine mühendislerinin istihdam edildiğini, eğitimlere önem verildiğini, seminerlere katılım sağlandığını, yabanc1 teknisyenler ile makinelerin tamir ve montajlarının yapıldığııı belirtmişlerdir.
İşletmelerin \%36.4'ü verimliliği arttıran bakım çalışmalarının başarısı için yeni yatırımların gerekli olduğunu belirtmişlerdir (Tablo 1). Bu yeni yatırımlar; çalıșanlara eğitim verilmesi, makine mühendislerinin alınması, makine yatırımlarının yapılması ve makine parkurunun geliştirilmesi şeklinde belirlenmiştir.

\section{Bakıma Yönelik Yapılan Çalışmalar}

İșletmelerin \%90.9'unda bakım talimatlarının uygulandığı görülmüştür. Makine ve ekipmanlarla ilgili kullanılma süresi, boş kalma süresi, bakım süresi gibi kayıtların işletmelerin \%50.6'sında tutulduğu belirlenmiștir.

İșletmelerin \%85.7'si makinelerin çalışma şartlarının (devir sayısı, kesici tipi, 
operatör tecrübesi) uygun olduğunu belirtmiştir. Makineler kullanıldıktan sonra temizlik ve günlük bakımlarının işletmelerin tamamı tarafından yapıldığı belirlenmiştir. Temizlik yönetimi işletmelerin \%46.8'inde operatör tarafindan, \%53.2'sinde bakım bölümü tarafından sağlanmaktadır. Sevim Korkut ve Beşikçi (2015) tarafindan yapılan çalışmada işletmelerin \%78.8'inde bakım talimatlarının uygulandığ donanımlarla ilgili kullanılma süresi, boş kalma süresi, bakım süresi gibi kayıtların işletmelerin \%57.6'sinda tutulduğu belirlenmiștir. Ayrıca ișletmelerin \%97'sinde makinelerin çalışma şartlarının uygun olduğunu ve \%90.9'unda makineler kullanıldıktan sonra temizliğinin ve günlük bakımlarının yapıldığını belirtmişlerdir.

İşletmelerin \%45.5'i günlük bakım, \%36.4'ü haftalık bakım, \%28.6's1 aylık bakım, \%5,2'si altı aylik bakım, \%3.9'u yıllık bakım ve \%6.5'i teknik destekli bakım uygulamaktadir.

İşletmelerin büyük bir çoğunluğu (\%72.7) yapılan bakım çalışmalarının kontrol ve denetlemesini yaptıklarını belirtmişlerdir.

İşletmelerin \%54.5'i makine yedek parça stoğu yaptıklarını ve yedek parçayı hem yurt içi hem de yurt dışından (\%76.6) temin ettiklerini belirtmişlerdir. İşletmelerde yedek parça temin edilmesi işlemi, işletmelerin \%71.4'ünde satın alma bölümü, \%20.8'inde bakım bölümü, \%7.8'inde her iki bölüm tarafından sağlanmaktadır.

İşletmelerde kesici ve delici takımların temin edilmesi faaliyeti ağırlıklı olarak satın alma bölümü (\%62.3) ve bakım bölümü (\%31.2) tarafindan yapılmaktadir. Satın alma ve bakım bölümü haricinde işletmeler diğer (\%6.5) seçeneği altında operatörlerce ve üretim bölümünce de satın alma faaliyeti yapıldığını belirtmişlerdir.

\section{Bakım Bölümünde Çalışanların Konumu}

İșletmelerin \%61'inde bakım mühendisi, \%20.8'inde bakım teknisyeni, \%40.2'sinde bakım ustabaşısı çalışmamaktadır. Bunların dişında işletmelerde (\%13) çalışan diğer elemanlar ise üretim bölümünde çalışanlar olarak belirlenmiştir (Tablo 2). Sevim Korkut ve Beşikçi (2015) tarafından Düzce ili orman ürünleri sanayisinde yapılan çalışmada da işletmelerin \%81.8'inde bakım mühendisi, $\% 60.6$ 'sında bakım teknisyeni ve \%48.5' inde bakım ustabaşısının çalışmadı̆̆ belirlenmiştir.

Tablo 2. İşletmelerin bakım bölümünde çalışanların konumu

\begin{tabular}{|c|c|c|c|}
\hline & Seçenekler & $\begin{array}{l}\text { İşletme } \\
\text { Sıklığı }\end{array}$ & $\begin{array}{c}\text { Yüzde } \\
(\%)\end{array}$ \\
\hline \multirow[t]{4}{*}{ Bakım mühendisi } & Çalışan yok & 47 & 61 \\
\hline & 1 kişi & 26 & 33.8 \\
\hline & 2 kişi & 3 & 3.9 \\
\hline & 3 kişi ve üzeri & 1 & 1.3 \\
\hline \multirow[t]{4}{*}{ Bakım teknisyeni } & Çalışan yok & 16 & 20.8 \\
\hline & 1 kişi & 24 & 31.2 \\
\hline & 2 kişi & 25 & 32.4 \\
\hline & 3 kişi ve daha fazla & 12 & 15.6 \\
\hline \multirow[t]{4}{*}{ Bakım ustabaşısı } & Çalışan yok & 31 & 40.2 \\
\hline & 1 kişi & 15 & 19.5 \\
\hline & 2 kişi & 25 & 32.5 \\
\hline & 3 kişi ve üzeri & 6 & 7.8 \\
\hline \multirow{4}{*}{ Diğer } & Çalışan yok & 67 & 87 \\
\hline & 1 kişi & 4 & 5.2 \\
\hline & 2 kişi & 5 & 6.5 \\
\hline & 3 kişi ve üzeri & 1 & 1.3 \\
\hline
\end{tabular}

\section{Uygulanan Bakım Yöntemleri}

İşletmelerin \%50.6'sında arıza olduğunda bakım, \%42.9'unda koruyucu bakım, \%39'unda kestirimci bakım, \%9.1'inde toplam verimli bakım uygulandığı belirlenmiştir (Tablo 3). 
Tablo 3. İşletmelerde uygulanan bakım yöntemleri.

\begin{tabular}{llcc}
\hline & Seçenekler & $\begin{array}{c}\text { İşletme } \\
\text { Sıklığ }\end{array}$ & $\begin{array}{c}\text { Yüzde } \\
(\mathbf{\%})\end{array}$ \\
\hline Arıza olduğunda bakım & Evet & 39 & 50.6 \\
\cline { 2 - 4 } & Hayır & 38 & 49.4 \\
\cline { 2 - 4 } & Toplam & $\mathbf{7 7}$ & $\mathbf{1 0 0}$ \\
\hline Koruyucu bakım & Evet & 33 & 42.9 \\
\cline { 2 - 4 } & Hayır & 44 & 57.1 \\
\cline { 2 - 4 } & Toplam & $\mathbf{7 7}$ & $\mathbf{1 0 0}$ \\
\hline Kestirimci bakım & Evet & 30 & 39 \\
\cline { 2 - 4 } & Hayır & 47 & 61 \\
\cline { 2 - 4 } & Toplam & $\mathbf{7 7}$ & $\mathbf{1 0 0}$ \\
\hline Toplam verimli bakım & Evet & 7 & 90.1 \\
\cline { 2 - 4 } & Hayır & $\mathbf{7 7}$ & $\mathbf{1 0 0}$ \\
\cline { 2 - 4 } & Toplam & & \\
\hline
\end{tabular}

Sevim Korkut (2005) Marmara Bölgesinde yapmış olduğu çalışmasında işletmelerin \%49.2'sinde arıza olduğunda bakım, \%41'inde koruyucu bakım ve \%9.8'inde TVB yöntemi uygulandığını belirtmiştir. Sevim Korkut ve Beşikçi (2015) Düzce ilinde yaptıkları çalışmalarında işletmelerin \%48.5'inin arıza olduğunda bakım, \%36.4'ünün koruyucu bakım, \%3'ünün kestirimci bakım ve \%12.1'inin TVB yöntemini uyguladığı belirlenmiştir.

\section{Bakımla İlgili Sorunlar}

İşletmelerin bakımla ilgili sorunları; işletmelerin \%16.9'unda teknik eleman eksikliği, \%13'ünde teknik destek eksikliği, \%7.8'inde personel yetersizliği, \%7.8'inde yedek parça temininde zorluk, \%3.9'unda atölye yetersizliğidir (Tablo 4). Sevim Korkut ve Beşikçi (2015) çalışmalarında işletmelerin bakımla ilgili sorunlarını; işletmelerin \%27.3'ünde teknik eleman eksikliği, \%12.1'inde teknik destek eksikliği, $\% 9.1$ 'inde personel yetersizliği, \%9.1'inde yedek parça temininde güçlük, \%3'ünde atölye yetersizliği olarak belirlemişlerdir.

Tablo 4. İşletmelerin bakımla ilgili sorunları.

\begin{tabular}{llcc}
\hline & Seçenekler & $\begin{array}{c}\text { İşletme } \\
\text { Sıklı̆̆ }\end{array}$ & $\begin{array}{c}\text { Yüzde } \\
\mathbf{( \% )}\end{array}$ \\
\hline Personel yetersizliği & Evet & 6 & 7.8 \\
\cline { 2 - 4 } & Hayır & 71 & 92.2 \\
\cline { 2 - 4 } & Toplam & $\mathbf{7 7}$ & $\mathbf{1 0 0}$ \\
\hline \multirow{2}{*}{ Teknik eleman eksikliği } & Evet & 13 & 16.9 \\
\cline { 2 - 4 } & Hayır & 64 & 83.1 \\
\cline { 2 - 4 } & Toplam & $\mathbf{7 7}$ & $\mathbf{1 0 0}$ \\
\hline Atölye yetersizliği & Evet & 3 & 3.9 \\
\cline { 2 - 4 } & Hayır & 74 & 96.1 \\
\cline { 2 - 4 } & Toplam & $\mathbf{7 7}$ & $\mathbf{1 0 0}$ \\
\hline Yedek parça temini zorluğu & Evet & 6 & 7.8 \\
\cline { 2 - 4 } & Hayır & 71 & 92.2 \\
\cline { 2 - 4 } & Toplam & $\mathbf{7 7}$ & $\mathbf{1 0 0}$ \\
\hline \multirow{2}{*}{ Teknik destek eksikliği } & Evet & 10 & 13 \\
\cline { 2 - 4 } & Hayır & 67 & 87 \\
\cline { 2 - 4 } & Toplam & $\mathbf{7 7}$ & $\mathbf{1 0 0}$ \\
\hline
\end{tabular}


$\begin{array}{ccc}\text { Makinelerin } & \text { Bakımsız Çalışması } \\ \text { Sonucunda Ortaya Çıkan Arızalar } \\ \text { İşletmelerde makinelerin bakımsız }\end{array}$ çalışması sonucu "parça kırılması", "sık sık rulman değiștirmek zorunda kalınması" ve "pnömatik ünitelerde arızalar" gibi arızaların nadiren etkili olduğu belirlenmiştir (Tablo 5).

Tablo 5. Makinelerin bakımsız çalışması sonucu ortaya çıkan arızalar.

\begin{tabular}{lcc}
\hline Seçenekler & Ortalama* & $\begin{array}{c}\text { Standart } \\
\text { Sapma }\end{array}$ \\
\hline Parça kırılması & 2.17 & 1.281 \\
\hline Pnömatik ünitelerde arızalar & 2.03 & 0.946 \\
\hline Sık sık rulman değiştirmek zorunda kalınması & 2.03 & 1.226 \\
\hline Motor yanması & 1.69 & 1.173 \\
\hline Aşırı zorlanma & 1.69 & 1.173 \\
\hline Yatak dağıtması & 1.62 & 1.052 \\
\hline
\end{tabular}

*1: Hiçbir zaman, 2: Nadiren, 3: Bazen, 4: S1k sık, 5: Her zaman

Uygun bakım çalışmaları ile bu arızalar; işletmelerin \%18.7'sinde \%30-49 oranında, $\% 68.7$ 'sinde $\% 70-95$ oranında, $\% 6.3$ 'ünde \%5-9 oranında ve \%6.3'ünde \%10-29 oranında azalmaktadır. Çözümlenemeyen arızalarda ise; işletmelerin \%88.3'ü yurt içinden, \%1.3'ü yurt dıșından ve \%10.4'ü hem yurt içi hem de yurt dışından destek sağlamaktadır.

\section{Alınan Güvenlik Önlemleri}

İşletmelerin \%45.5'inde bakım çalışmaları sırasında oluşan iş kazalarına karş1 önlemlerin alındığ 1 belirlenmiştir. İşletmeler alınan önlemler arasında; İş Sağlığı ve Güvenliği Birimi (ISSGB)'nin bulunduğunu, A sınıfi İş Sağlığı ve Güvenliği (İSG) uzmanının çalıştığını, risk analizlerinin yapıldığını, operatörlere eğitimlerin verildiğini, bakım çalışmalarının üretime ara verilerek yapıldığını, her makinede temizlik ve kullanımı ile ilgili yazıların bulunduğunu, uyarı levhalarının konulduğunu, koruyucu malzemelerin kullanıldığını belirtmişlerdir.

\section{TVB Uygulamaları}

TVB konusunda bilgi sahibi olan işletmelerin sayıs1 $29 \quad(\% 37.7)$ olarak belirlenmiştir. İşletmelerin \%40,2'si TVB çalışmalarından kısmen haberdar iken, $\% 22.1$ 'inin ise haberi bulunmamaktadır (Tablo 6). TVB'yi tam olarak uygulayan 1 (\%1.3) işletme ve kısmen uygulayan 10 (\%13) işletmenin olduğu belirlenmiștir. İşletmelerin büyük bir çoğunluğu (\%85.7) ise TVB'yi uygulamamaktadır. TVB'yi kısmen ya da tam olarak uygulayan ișletmelerden 10'u, TVB'nin uygulanmasina 1-2 yıl önce başladıklarını belirtmişlerdir (Tablo 6).

Tablo 6. İşletmelerde TVB uygulamaları.

\begin{tabular}{|c|c|c|c|}
\hline & Seçenekler & $\begin{array}{c}\text { İşletme } \\
\text { Sıklığı }\end{array}$ & $\begin{array}{c}\text { Yüzde } \\
(\%)\end{array}$ \\
\hline \multirow{3}{*}{ TVB çalışmalarından haberiniz var mı? } & Evet & 29 & 37.7 \\
\hline & Kismen & 31 & 40.2 \\
\hline & Hayır & 17 & 22.1 \\
\hline \multirow{3}{*}{ İşletmenizde TVB ilkelerini şu anda uyguluyor musunuz? } & Evet & 1 & 1.3 \\
\hline & Kismen & 10 & 13 \\
\hline & Hayır & 66 & 85.7 \\
\hline \multirow{4}{*}{$\begin{array}{l}\text { Cevabınız Evet ya da Kısmen ise TVB'yi uygulamaya ne } \\
\text { kadar zaman önce başladınız? }\end{array}$} & $1-2$ y1l & 10 & 90.9 \\
\hline & $3-4$ y1l & - & - \\
\hline & 5 y1l ve üzeri & 1 & 9.1 \\
\hline & Toplam & 11 & 100 \\
\hline
\end{tabular}


TVB'yi tamamen ve kısmen uygulayan toplam 11 işletmeden 9'u üniversitelerin danışmanlığında TVB çalışmalarına başladıklarını belirtmişlerdir.

TVB'nin Bugünkü Durumu

TVB'yi uygulayan 11 işletmede TVB'nin şu andaki durumu; 6 işletmede hazırlık aşamasında, 4 işletmede uygulama aşamasının yaklaşık olarak ortasında ve 1 işletmede programın çoğunluğu tamamlanarak devam etmektedir. TVB'yi uygulayan 4 işletme belli kurallara göre çalışıldığını belirtmiştir (Tablo 7).

Tablo 7. İşletmelerde uygulanan TVB'nin bugünkü durumu

\begin{tabular}{|c|c|c|c|}
\hline & Seçenekler & $\begin{array}{l}\text { İşletme } \\
\text { Sıklığı }\end{array}$ & $\begin{array}{c}\text { Yüzde } \\
(\%)\end{array}$ \\
\hline \multirow{8}{*}{$\begin{array}{l}\text { İşletmenizde uyguladığınız } \\
\text { TVB'nin şu andaki } \\
\text { durumu nedir? }\end{array}$} & Hazırlık aşamasında & 6 & 54.5 \\
\hline & Uygulama aşamasının yaklaşık olarak ortasında & 4 & 36.4 \\
\hline & Çoğunluğu tamamlandı, program devam ediyor & 1 & 9.1 \\
\hline & Program başarılı bir şekilde tamamlandı & - & - \\
\hline & Program başlatıldı fakat devam edilmedi & - & - \\
\hline & $\begin{array}{l}\text { Program başlatıldı fakat devam edilmedi. Tekrar } \\
\text { başlamak için niyet edildi }\end{array}$ & - & - \\
\hline & Bilinmiyor & - & - \\
\hline & Toplam & 11 & 100 \\
\hline \multirow{3}{*}{$\begin{array}{l}\text { TVB'de belli kurallara } \\
\text { göre çalış1lıyor mu? }\end{array}$} & Evet & 4 & 36.4 \\
\hline & Kismen & 7 & 63.6 \\
\hline & Toplam & 11 & 100 \\
\hline
\end{tabular}

\section{TVB İle Sağlanan Yararlar}

Katılımcı işletme temsilcilerinin "TVB uygulamalarının bir sonucu olarak sağlanan yararları derecelendiriniz?" sorusuna verdikleri yanıtların sonuçları Tablo 8 'de verilmiștir.

Tablo 8. İșletmelerde TVB ile sağlanan yararlar

\begin{tabular}{lcc}
\hline Seçenekler & Ortalama* & $\begin{array}{c}\text { Standart } \\
\text { Sapma }\end{array}$ \\
\hline Verimlilik arttı & 4.18 & 0.603 \\
\hline Hurda oranları azald 1 & 4.18 & 0.405 \\
\hline Toplam ekipman verimliliği arttı & 4.09 & 0.302 \\
\hline Üretim giderleri azald 1 & 4.09 & 0.302 \\
\hline Arızalar azaldı & 4.00 & 0.000 \\
\hline Müşteri şikayetleri azaldı & 3.91 & 1.044 \\
\hline İş kazaları azaldı & 3.91 & 0.539 \\
\hline Mamul ve yarı mamul envanteri azaldı & 3.82 & 0.603 \\
\hline
\end{tabular}

*1: Kesinlikle katılmıyorum, 2: Katılmıyorum, 3: Kararsızım, 4: Kat1liyorum, 5: Kesinlikle katıllyorum

Katılımcı işletmelere göre; işletmelerinde TVB'nin uygulanması sonucunda sağlanan yararlar olarak "verimlilik arttı", "hurda oranları azaldı", "toplam ekipman verimliliği arttı", "üretim giderleri azaldı", "arızalar azaldı" gibi yargılar gösterilmiştir. $\mathrm{Bu}$ yargıların yanı sıra "müşteri şikayetleri azaldı", "iş kazaları azaldı", "mamul ve yarı mamul envanteri azaldı" yargıları da işletmeler tarafından TVB uygulaması ile sağlanan yararlar arasında belirtilmiştir (Tablo 8).

\section{TVB Uygulama Sonuçları}

İşletmelerde TVB'nin uygulanması sonucunda sağlanan yararların ölçümü, toplam başarı oran1, ve gelecek y1llarda uygulanmasına yönelik elde edilen bulgular Tablo 9'da verilmiştir. 
Tablo 9. İșletmelerde TVB uygulama sonuçları

\begin{tabular}{|c|c|c|c|}
\hline & Seçenekler & $\begin{array}{c}\text { İşletme } \\
\text { Sıklığı }\end{array}$ & $\begin{array}{c}\text { Yüzde } \\
(\%)\end{array}$ \\
\hline \multirow{4}{*}{ TVB'nin yararları işletmenizde ölçüldü mü? } & Evet & 1 & 9.1 \\
\hline & Hayır & 7 & 63.6 \\
\hline & Kismen & 3 & 27.3 \\
\hline & Toplam & 11 & 100 \\
\hline \multirow{6}{*}{$\begin{array}{l}\text { Uyguladığınız TVB'nin toplam başarı oranı } \\
\text { nasıldır? }\end{array}$} & Çok iyi & - & - \\
\hline & \begin{tabular}{|l|l} 
İyi \\
\end{tabular} & 3 & 27.3 \\
\hline & Memnun edici & 8 & 72.7 \\
\hline & Kötü & - & - \\
\hline & Zayif & - & - \\
\hline & Toplam & 11 & 100 \\
\hline \multirow{5}{*}{ Gelecek yıllarda TVB uygulayacak misınız? } & Evet & 13 & 16.9 \\
\hline & Hayır & - & - \\
\hline & Kismen & 2 & 2.6 \\
\hline & Bilinmiyor & 62 & 80.5 \\
\hline & Toplam & 77 & 100 \\
\hline
\end{tabular}

TVB'nin uygulanmasi sonucunda sağlanan yararlar 3 işletmede kısmen olmak üzere 4 işletme tarafindan ölçüldüğü belirlenmiştir. Ölçüm sonuçlarında TVB'nin toplam başarı oranı; iyi (\%27.3) ve memnun edici (\%72.7) olarak değerlendirilmiştir (Tablo 9).

Gelecek y1llarda işletmelerin \%19.5'inin TVB'yi uygulamak istedikleri, \%80.5'inin ise TVB uygulama konusunda kararsiz oldukları belirlenmiștir. İşletmeler gelecek y1llarda TVB uygulama nedenleri olarak; arızaların azalması, verimliliğin artması, üretim giderlerinin azalması, iş kazalarının azalması, kalitenin artması, sürekli iyileşmenin sağlanması, müşteri memnuniyetinin sağlanması, yanıtlarını vermişlerdir.

\section{Sonuç ve Öneriler}

İşletmelerin bakım faaliyetlerine bakıldığında; işletmelerin \%75.3'ünde bakım bölümünün organizasyon şemasinda bağımsız bir bölüm olarak yer aldığ görülmektedir. İșletmelerin \%53.2'sinde bakım bölümünün gelişme gösterdiği belirlenmiştir. İşletmelerin \%36.4'ü verimliliği arttıran bakım çalışmalarının başarısı için; çalışanlara eğitim verilmesini, makine mühendislerinin bakım bölümüne alınmasını, makine yatırımlarının yapılmasını ve makine parkurunun geliştirilmesi gibi yeni yatırımların gerekli olduğunu belirtmișlerdir.

İşletmelerde arızaların en kısa sürede çözümlenebilmesi için eğitimli bakım onarım ekibine ihtiyaç duyulurken bu ekibin sürekli olarak eğitimine önem verilerek, arızalara eğitimli personelin müdahale etmesi sağlanmış olunacaktır. Oysaki araştırma yapılan işletmelerin \%61'inde bakım mühendisi, \%20.8'inde bakım teknisyeni, $\%$ 40.2'sinde bakım ustabaşısı çalışmamaktadır.

İșletmelerin \%90.9'unda bakım talimatlarının uygulandığ bakım ve arıza ile ilgili kayıtların (makine ve ekipmanlarla ilgili kullanılma süresi, boş kalma süresi, bakım süresi) tutulduğu belirlenmiştir. İşletmelerin tamamı makineler kullanıldıktan sonra temizlik ve günlük bakımın operatör (\%46.8) ve bakım bölümü (\%53.2) tarafindan yapıldığını belirtmişlerdir.

İşletmelerde makinelerin bakımsız çalışması ile ortaya çıkan arızalar; parça kırılması, s1k s1k rulman değiştirmek zorunda kalınması ve pnömatik ünitelerde arızalar olarak belirlenmiştir. Uygun bakım çalışmaları ile bu arızaların işletmelerin \%68.7'sinde \%70-95 oranında azalabildiği çalışma sonucunda ortaya çıkarılmıştır. Bu nedenle, sektör işletmelerinin işletme yapılarına uygun bakım planlaması yapması önerilmektedir. İşletmelerde kesici ve delici takımların çoğunlukla (\%62.3) satın alma bölümüne bağl1 olduğu belirlenmiştir. Kesici ve delici takımların işletmelerde satın alma bölümüne bağlı olması, TVB uygulamasının her bölümün uygulamaya katılmasını ve 
çalışmaları sahiplenmesini hedefleyen bir sistem olması ile açıklanabilir. Ancak, satın alma bölümünün kesici ve delici takımların işletme için ne kadar acil olduğu ve termin süresinin ne olması gerektiği konusunda fikirlerinin olmaması durumunda parçaları zamanında getirtemeyerek üretimde aksamalar yaşanabilir.

İșletmelerde uygulanan bakım yöntemi olarak arıza olduğunda bakım (\%50.6) ilk sıradadır. Planlı bakım yöntemlerinin uygulanma düzeyi değerlendirildiğinde, işletmelerin \%42.9'unun koruyucu bakım, \%39'unun kestirimci bakım, \%9.1'inin TVB yöntemini uyguladığı görülmektedir.

TVB çalışmalarından işletmelerin \%37.7'sinin tamamen, \%40.2'sinin kismen haberdar olduğu, \%22.1'inin TVB uygulamasının ne olduğuna dair hiçbir bilgisi olmadığı belirlenmiştir.

TVB konusunda bilgi sahibi olan işletmelerin TVB'yi uygulamaya geçmeyi sürekli erteledikleri görülmüştür. Gelecek y1llarda işletmelerin sadece \%19.5'inin TVB uygulamasına geçmeyi düşündükleri belirlenmiștir. TVB uygulama konusunda kararsız olan işletmeler (\%80.5), TVB ve TVB'nin işletmelere sağlayacağ 1 yararlar konusunda bilgi sahibi olmadıklarından dolayı uygulamaya gereksinim duymadıklarını belirtmişlerdir.

İşletmeler TVB uygulaması sonucunda; hurda oranının, üretim giderlerinin, arızaların, müşteri şikayetlerinin, iş kazalarının azaldığını belirtmişlerdir. Ayrıca, verimlilik ve ekipman verimliğinde artışların yaşandığını vurgulamışlardır.

TVB sisteminin orman ürünleri endüstrisinde uygulama alanı bulabilmesi, çalışanların tamamının katılımlarının sağlanabilmesi ve çalışanların uygulamayı benimseyebilmeleri için aşağıdaki öneriler yapılabilir.

- Üretim için makine seçimi yapılırken satıcı firmadan özellikle düzenli bakımları konusunda garantiler alınmalı ve bunlar alım sözleşmesinde açık bir şekilde belirtilmelidir.

- Sifir ariza ve sifir hata hedeflerine ulaşılması için günlük muayene, yağlama ve hassasiyet kontrollerini içeren bir bakım programı uygulamaya alınmalıdır. Her işletmenin bir bakım yönetim sistemi olmalı ve bu sistemi uygulayacak teknik elemanı (mühendis, tekniker) bünyesinde bulundurmalıdir.

- İşletmelerde stratejik kararların alınmasında profesyonel kişilerin söz sahibi olmas1, bakım bölümünün makine mühendisi ve teknik elemanlardan oluşması gerekir. İşletmelerde makine yatırımlarında ya da makinelerde yapılacak değişikliklerde bakım bölümüne danıșılarak hareket edilmelidir. Bu şekilde, bakım bölümünün gerektiği gibi bakım programlarını yapıp düzenli ve kontrollü bir şekilde ilerlemesi sağlanabilir.

- Bakım konusunda ortak bir dil olușturulmalı, sanayi, üniversite ve meslek odaları arasında işbirliği sağlanmalıdır.

- Üst yönetimin kuvvetle uygulamaya destek çıkmasını, TVB uygulamasının üretim, bakım bölümü ve idari yönetimle bir bütün olarak düşünülüp herkesin en etkili şekilde bu çalışmanın içinde yer almasını sağlamak gerekir.

- TVB işletmelerin yapısına göre uygulanmalıdır. Çünkü her işletmenin yerleşimi, ürettiği ürünler, organizasyon yapıs1, yörenin tarihsel gelişimi ve işletme çevresindeki kültürü farklıdır.

- TVB ile, çalışanların kullandığı ekipman üzerinde sorumluluğu ve işini daha iyi yapması sağlanır. Bu anlayış çerçevesinde sürekli eğitimler verilerek çalışanların motivasyonları ve verimlilikleri artırılabilir.

- İşletmelerin gerek üretim bölümünde gerekse de bakım bölümünde donanımlı ve bilgili mühendislerle çalışması gerekmektedir. İşletmelerin bu şekilde profesyonel üretim ve bakım çalışmaları yapabilecekleri açıktır. Bunun sonucunda işletmeler TVB uygulamalarının getirdiği faydalardan yararlanabileceklerdir.

- TVB 3-4 y1lı kapsayan bir geliştirme programı olduğu için, ilk yılın sonunda elde edilen veriler neticesinde işletmenin TVB'den umduğu sonuçlara ulaşamamış olduğu düşünülebilir. Ancak işletmeler, programın devamlılığını sağlayarak kayıların azaltılmasinı ve ekipman verimliliğini artırmayı başaracaklarını unutmamalıdırlar.

- TVB uygulaması yapılacak işletmenin iyi 
analiz edilerek; ișletmenin ișleyișine, imkanlarına, teknolojik durumuna, organizasyonel yapısına, çalışanların becerilerine ve deneyimlerine göre uyumunun iyi yapılması sağlanmalıdır.

- TVB uygulayan ve başarı sağlayan işletmeler; TVB sonuçlarını ve deneyimlerini sektördeki diğer işletmelerle ve üniversitelerin ilgili bölümleriyle paylaşacağ 1 ortak platformlar oluşturmalıdır. $\mathrm{Bu}$ amaçla, üniversitesanayi işbirliğine gidilerek bu konudaki bilgi ve uygulama eksikliklerinin giderilmesine çalışılmalıdır.

- Üniversitelerin ilgili bölümleri eğitim programlarında TVB konusuna yer vererek, Yüksek Lisans ve Doktora Tez çalışma sayılarını arttırmalıdır.

TVB modelinin oluşturulması ve uygulanması işinin üst yönetimin desteğine ihtiyaç duyularak gerçekleştirilebileceği, çalışanların kendi kendilerini kontrol edebilme anlayışının oluşması ve bir bakımcı gibi düşünebilmelerinin uzun zaman ve mücadele gerektiren işler olduğu, bu uygulamalar sonucunda da işletmelerin daha verimli bir şekilde çalışabilecekleri unutulmamalıdır (Bozkurt Küçük, 2016).

\section{Teşekkür}

$\mathrm{Bu}$ çalışma, Düzce Üniversitesi "BAP2013.02.HD.085" numaralı Bilimsel Araştırma Projesiyle desteklenmiştir.

$\mathrm{Bu}$ çalışma, Düzce Üniversitesi Fen Bilimleri Enstitüsü Orman Endüstri Mühendisliği Anabilim Dalı'nda yapılan "Orman Ürünleri Endüstrisinde Toplam Verimli Bakıma Yönelik Sektörel Altyapının Belirlenmesi, İnegöl Örneği” başlıklı Yüksek Lisans Tezinin bir bölümüdür.

\section{Kaynaklar}

Adalı S., 1998. Toplam verimli bakım faaliyetlerinin üretim yönetimine etkileri. Yüksek Lisans Tezi, Kocaeli Üniversitesi Sosyal Bilimler Enstitüsü, $115 \mathrm{~s}$. Kocaeli.

Akteke N., 2007. Toplam verimli bakım planlaması ve bir uygulaması. Yüksek Lisans Tezi, Akdeniz Üniversitesi Sosyal Bilimler Enstitüsü, 102 s. Antalya.

Al-Hassan K., Fat-Lam Chan J., Metcalfe A.V. 2000. The role of total productive maintenance in business excellence. Total Quality Management, 11 (4-6), 596-601.
Anonim, 2012. İnegöl Ticaret ve Sanayi Odas1 Üye Kayıt Listeleri.

Aytin A., 2006. Düzce ili orman ürünleri endüstrisinin mevcut durumu, sorunları ve çözüm önerileri. Yüksek Lisans Tezi, Zonguldak Karaelmas Üniversitesi Fen Bilimleri Enstitüsü, 135 s. Bartın.

Ayyıldız R., 2000. Toplam verimli bakım ve bir sanayi işletmesinde uygulama. Yüksek Lisans Tezi, Gazi Üniversitesi Sosyal Bilimler Enstitüsü, 144 s. Ankara.

Bayram A., 1998. Toplam verimli bakımın üretim yönetimine katkıları ve bir uygulama. Yüksek Lisans Tezi, Kocaeli Üniversitesi Sosyal Bilimler Enstitüsü, 125 s. Kocaeli.

Bozkurt Küçük B., 2016. Orman ürünleri endüstrisinde toplam verimli bakıma yönelik sektörel altyapının belirlenmesi, İnegöl örneği. Yüksek Lisans Tezi, Düzce Üniversitesi Fen Bilimleri Enstitüsü, 109 s. Düzce.

Bozoğlu M.Ö., 1998. toplam üretken bakım (T.P.M.) ve uygulaması. Yüksek Lisans Tezi, Anadolu Üniversitesi Sosyal Bilimler Enstitüsü, 106 s. Eskișehir.

Cihan N., 2005. Toplam kalite yönetimi, tam zamanında üretim ve toplam üretken bakım yönetim yaklaşımlarının entegrasyonun Türk prefabrikasyon sektöründe uygulanabilirliği. Yüksek Lisans Tezi, İstanbul Teknik Üniversitesi Fen Bilimleri Enstitüsü, 181 s. İstanbul.

Çelebi H.T., 1997. Toplam kalite açısından 5S ve toplam verimli bakım. Yüksek Lisans Tezi, İstanbul Üniversitesi Fen Bilimleri Enstitüsü, 92 s. İstanbul.

Demir F., 2009. Yalın üretimde toplam üretken bakım ve hızlı kalıp değiștirme (SMED) uygulamasi. Yüksek Lisans Tezi, Gebze Yüksek Teknoloji Enstitüsü Sosyal Bilimler Enstitüsü, 136 s. Gebze.

Doğan E., 2010. Toplam üretken bakım uygulamasından başarı sağlamada örgütsel öğrenmenin rolü ve bir üretim işletmesindeki uygulama. Yüksek Lisans Tezi, Eskişehir Osmangazi Üniversitesi Sosyal Bilimler Enstitüsü, $148 \mathrm{~s}$. Eskişehir.

Elvan F., 2012. Türkiye'de başarılı toplam verimli bakım uygulaması yapan seçilmiș kuruluşların kıyaslanması. Yüksek Lisans Tezi, Erciyes Üniversitesi Fen Bilimleri Enstitüsü, 176 s. Kayseri.

Erdem E., 2009. Küçük ve orta ölçekli işletmelerin (KOBİ) sorunları, Düzce ili orman ürünleri sanayisi örneği. Yüksek Lisans Tezi, Düzce Üniversitesi Fen Bilimleri Enstitüsü, 107 s. Düzce.

Genç A., 2007. Toplam verimli bakım ve uygulamasi. Yüksek Lisans Tezi, Erciyes Üniversitesi Fen Bilimleri Enstitüsü, 147 s. 
Kayseri.

Geniş U.O., 2007. Bir üretim işletmesinde toplam verimli bakım uygulaması. Yüksek Lisans Tezi, Dumlupınar Üniversitesi Fen Bilimleri Enstitüsü, 83 s. Kütahya.

Göktaş C., 1997. Toplam verimli bakım ve Kordsa'daki toplam verimli bakım uygulamalarının değerlendirilmesi. Yüksek Lisans Tezi, İstanbul Teknik Üniversitesi Fen Bilimleri Enstitüsü, 217 s. İstanbul.

Görener A., Yenen V.Z. 2007. İșletmelerde toplam verimli bakım çalışmaları kapsamında yapılan faaliyetler ve verimliliğe katkıları. İstanbul Ticaret Üniversitesi Fen Bilimleri Dergisi, 6(11), 2007/1, 47-63.

İșaşır İ.E., 2006. Toplam verimli bakım ve bir firma örneği. Yüksek Lisans Tezi, Karadeniz Teknik Üniversitesi Sosyal Bilimler Enstitüsü, 124 s. Trabzon.

Kekezoğlu Y.E., 2006. Toplam kalite yönetimi anlayışında yalın üretimde toplam üretken bakım süreci ve uygulamaları. Yüksek Lisans Tezi, Marmara Üniversitesi Sosyal Bilimler Enstitüsü, 193 s. İstanbul.

Nakajima S., 1988. Introduction to TPM: Total productive maintenance. ISBN:0-91529923-2, 115 p, Productivity Press, Portland, Oregon.

Özdamar K., 2002. Paket programlar ile istatistiksel veri analizi. Kaan Kitabevi.

Öztürk N., 1999. Toplam verimli bakımın üretim yönetimine etkileri ve bir uygulama. Yüksek Lisans Tezi, İstanbul Üniversitesi Sosyal Bilimler Enstitüsü, 136 s. İstanbul.

Sevim Korkut D., 2005. Toplam bakım yönetimi ve orman ürünleri işletmesinde uygulanması. Doktora Tezi, İstanbul Üniversitesi Fen Bilimleri Enstitüsü, 198 s. İstanbul.

Sevim Korkut D., Beşikçi M., 2015. Orman ürünleri endüstrisinde bakım faaliyetlerinin incelenmesi; Düzce ili örneği. Düzce Üniversitesi Ormanc1l1k Dergisi, 11(2), 13-22.

SPSS, 2003. Institute Inc., SPSS Base 12.0 User's Guide, 703 p.

Tazegün A., 2009. Toplam verimli bakım ve çimento sektöründe uygulamaları. Yüksek Lisans Tezi, Trakya Üniversitesi Fen Bilimleri Enstitüsü, 105 s. Edirne. 